This report was prepared as an account of work sponsored by the United States Government. Neither the United States nor the United States Atomic Energy Commission, nor any of their employees, nor any of their contractors, subcontractors, or their employees, makes any warranty, express or implied, or assumes any legal liability or responsibility for the accuracy, completeness or usefulness of any information, apparatus, product or process disclosed, or represents that its use would not infringe privately owned rights.

Printed in the United States of America. Available from National Technical Information Service

U. S. Department of Commerce 5285 Port Royal Road Springfield, Virginia 22151

Price: Printed Copy $\$ 3.00$; Microfiche $\$ 0.95$ 


\title{
Determination of Oxygen in Irradiated Reactor Fuels and Cladding Materials
}

\author{
by \\ Carolyn S. MacDougal! \\ Maynard E. Smith \\ Glenn R. Waterbury
}

Work supported by the Division of Reactor Development and Technology. 


\begin{abstract}
A BSTRACT
A mcthod for determining oxygen was adapted and remotized for analysis of irradiated fuels and claddings in a hot cell. The sample is reacted with carbon at $2000{ }^{\circ} \mathrm{C}$ to liber:ate oxygen as carbon monoxide and dioxide which are measured gravimetrically or manometrically, depending on their quantities. Oxide fuels are inixed with graphite and pressed into pellets before the reaction. The evolved carbon dioxide is absorbed on Ascarite and weighnd, and the carbon monoxide is oxidized over copper oxide to carbon dioxide before being trapped and weighed. The oxygen content is calculated from the weight increases of the two tubes. Analyses of $1-\mathrm{g}$ samples of oxide fuels that had undergone 6.5 and 8.5 at. \% burnup showed that the relative standard deviation of the method is $0.4 \%$.

Carbide fuel and cladding samples, which have low oxygen contents, generate only carbon monoxide when heated to $2000^{\circ} \mathrm{C}$ in a graphite crucible containing platinum. The carbon monoxide is oxidized by Schutze reagent to carbon dioxide which is collected in a capillary trap and measured manometrically. The relative standard deviation of this method is $10 \%$ in the analysis of $100-\mathrm{mg}$ samples of carbide fuel or cladding.
\end{abstract}

\section{INTRODUCTION}

The dependence of the properties of refractory fuels and cladding materials upon their oxygen contents necessitated development of a method ${ }^{1-3}$ for accurately determining this constituent or impurity. In addition, this method is needed in studies of oxyger migrations during burnup of the fuel. The method also is used in estimating the oxygento metal atom ratio of oxide fuels, provided the metal contents are also measured. Experience with the gravimetric method for determining oxygen in oxides has been so satisfactory that its modification for use in a remote facility did not present insurmountable difficulties. In the interest of economical use of equiprent and of space in a hot cell, only the furnace originally designed for heating oxide samples was installed, with the option of using eithei a gravimetric or manometric finish. The combined method is sensitive enough for measurement of microgram quantities of oxygen in carbides and claddings, and yet gives satisfactory precision in measuring oxygen in the oxide fuels. The method has been applied to date to the analysis of (uranium, plutonium) dioxides, uranium oxides, ana stainless steel cladding samples.

The equipment used, therefore, is extremely versatile, being able to measure microgram or milligram quantities of oxygen. The method applies equally well to any material that reacts completely with carbon in an inert atmosphere but does not form volatile products other than carbon monoxide or carbon dioxide.

\section{APPARATUS AND REAGENTS \\ Apparatus $^{4}$}

Absorption Tubes, 100-ml Schwartz (two required). Fill two-thirds of each tube with Ascarite, and th: remaining third with anhydrous magnesium perchlorate. Pack the openings to both tubes with glass wool to prevent physical loss of dust from the tubes. 
Balance, analytical, with nonbrowning glass, Ainsworth Right-a-Weigh or similar.

Balance, analytical, for weighing absorption tubes, Ainsworth $\mathrm{BCT}$ or similar, with set of $\mathrm{S}-$ grade weights.

Ball Bearings, 0.25-in.-diam, chrome steel. Base Plate, brass, for sealing furnace tube, see Fig. 1.

Blender, yoke, see Fig. 2

Boat, sample, glass. Cut off the top half of a 30$\mathrm{ml}$ beaker, so that the remaining cup is $1-1 / 8-$ in. high.

Brush, for cleaning die plunger, see Fig. 3 . Brushes, brass, 12 -gauge shotgun and 0.27 calibre rifle, for cleaning die and grinding capsule. Combustion Train, Arrange the equipment listed here as shown in Fig. 4.

Desiccent Tube, prepare by filling three-fourths of a 200-ml Schwartz tube with anhydrous magnesium

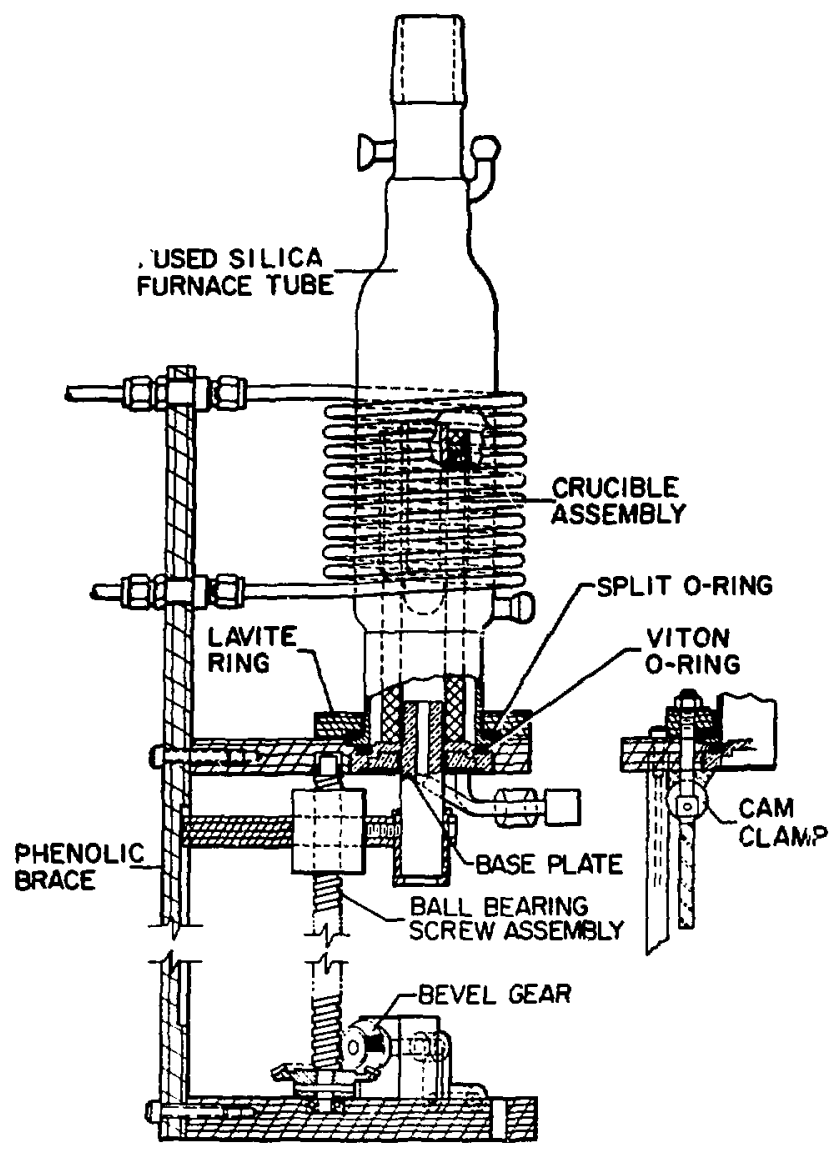

Fig. 1. Furnace, brace, and base plate.

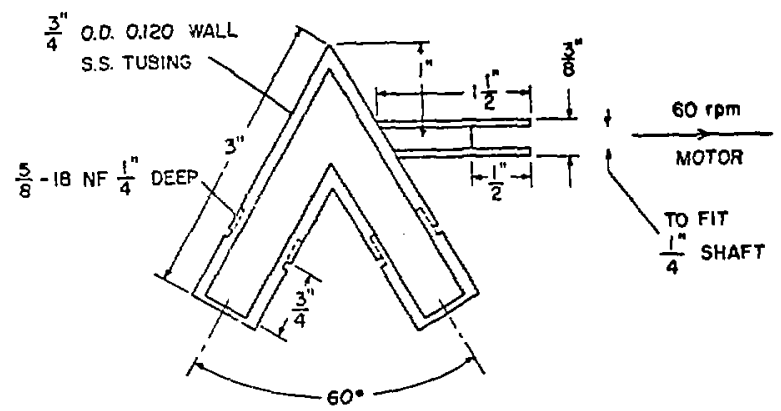

Fig. 2. Yoke blender.

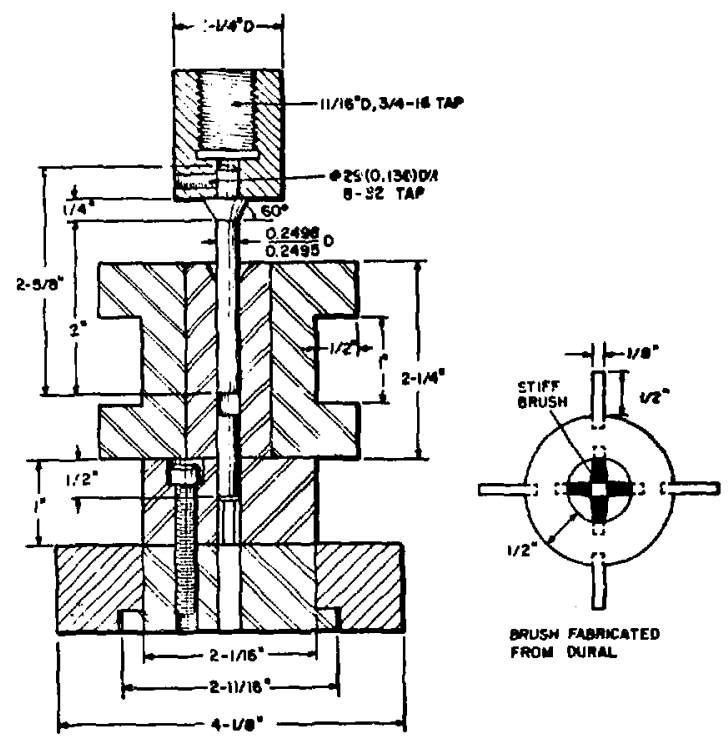

Fig. 3. Pellet die and brush.

perchlorate. Fill the remaining one-fourth of the tube with Schutze reagent. Pack the openings of the tube with glass wool to prevent dust from passing into the analytical train.

Dewar, 2.93-in.-i.d., 6-in. -high, to fit under manometer.

Die, 0.25-in. pellet die, see Fig. 3 .

Drying Tower, stainless steel, 30-in. -long, 3-in. diam, having a screw cap fitted with an O-ring to make a gastight seal, filled with molecular seive. Engraving Tool, Vibrograver or similar. Flow Gauge, Hoke Bantam or similar. Funnel, for pouring sample into die, see Fig. 5 . Furnace Tube, fused-silica, see Fig. 1. Furnace Tubes, nickel, 16-in.-long, 1.125-in. - 


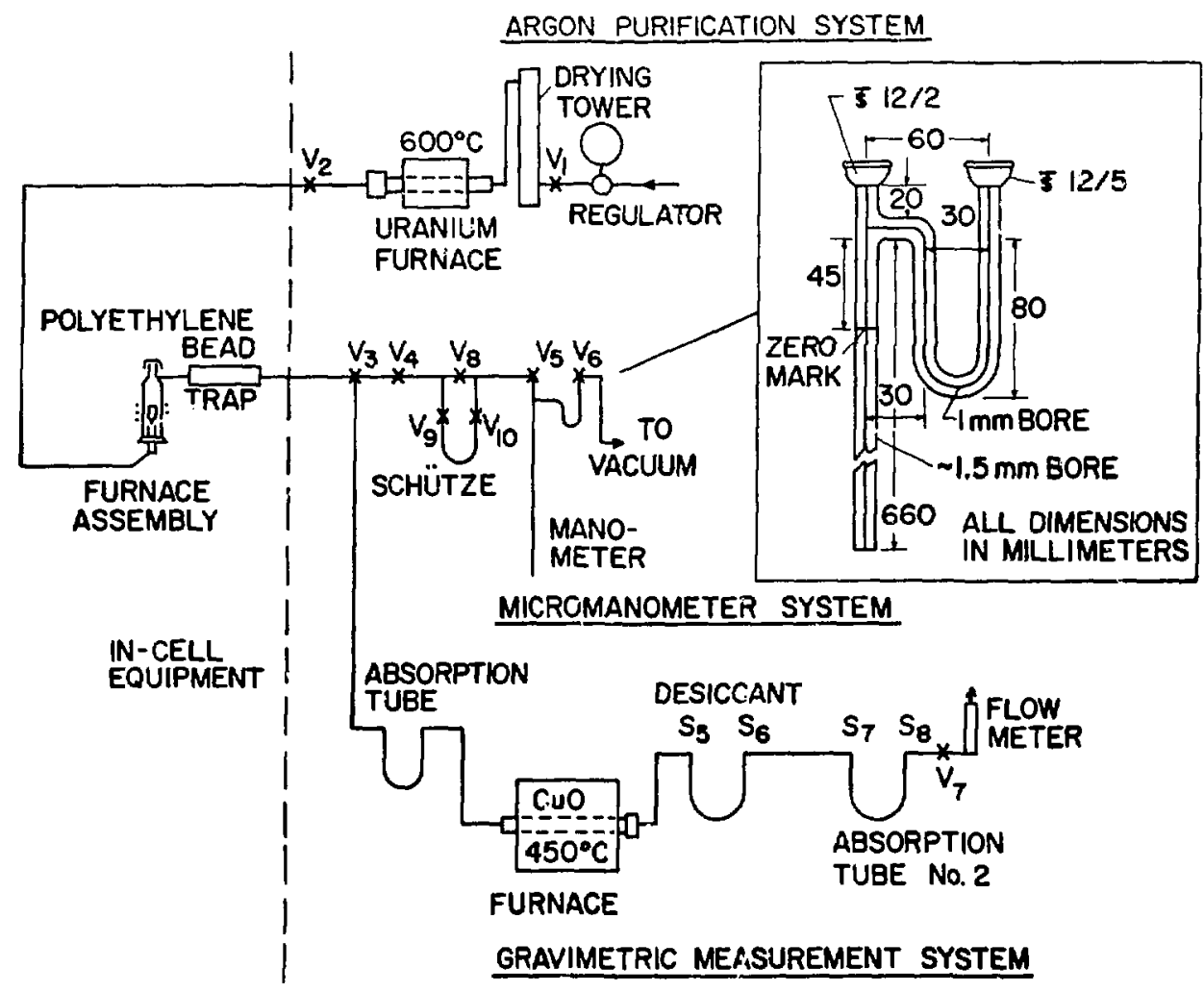

Fig. 4. Combustion train with insert of manometer.

diam, having a screw cap fitted with a lead gazket to $m_{c}$ ie a gastight seal, to fit resistance furnaces, two required.

Furnaces, tube, 1,25-in, -bore, 12-in. Hevi-Duti or similar, two required, with 7 .5-A var.iable transformers for temperature control.

Generator, induction, 25-kW, Lepel Type T-751-32 or similar.

Guide Tube, to guide sample into crucible, $0.825-$ in. $-0 . d,, 8,5-i n .-$ long, with bottom recessed to $0.625-$ in. o.d.

Lift, mechanical, see Fig. 1.

Manometer, with meter stick, see Fig. 4. Mixer-Mill, Spex Type 8000 II or similar, with Spex 8004 tungsten carbide grinding vial (50-g quantities of oxide) and Crescent dental capsule 6114 (2to 5 -g quantities of oxide).

Moto Tool, Dremel Mfg. Co. Model 270 or similar, two required. Nodify each to accept gun brushes previously described.

O-Ring, Viton, 2.125-in.-i.d. by 2.5-in.-o.d.

Pedestal, boron nitride, see Fig. 6 .
Pellet-Grasping Tool, see Fig. 7 .

Pellet Trough, see Fig. 8

Pyrometer, graduated from 0 to $1000^{\circ} \mathrm{C}$, Sim-Ply Trol Assembly Products, Inc., or equivalent, with Chromel-Alumel thermocouples, two required.

Regulator, low-pressure, measuring 0 to 50 in. water, Moore Products or similar.

Remote Facility, similar to that described by Lilientha ${ }^{5}$ and by Burwell, Schulte, and Wilson. ${ }^{6}$

Ring, Lavite, for binding furnace to base plate, see Fig. 1.

Thimble Assembly, with crucible, cap, and insulation, see Fig. 6.

Trap, straight length of 12-mm-i.d, tubing filled with $25-\mathrm{g}$ polyethylene beads, for removal of fission products.

Tweezers, 12-in. -long, suitably modified for easy handling by manipulators.

U-Tube, filled with $50 \mathrm{~g}$ of Schüze reagent.

Vacuum Pump, Cenco, Hyvac, Model 91135, or similar.

Weighing Scoopula, suitably modified for manipulators. 

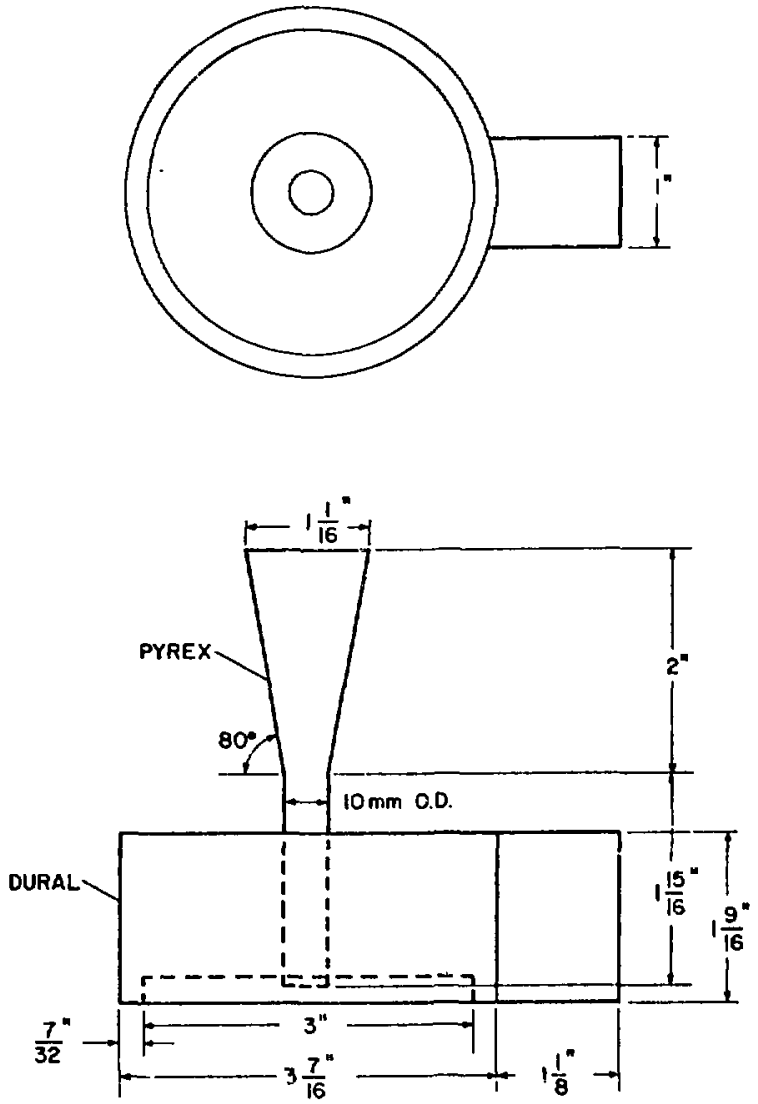

Fig. 5. Funnel.

\section{Reagents}

Argon, tank.

Ascarite, 8- to 20-mesh.

Copper Oxide, wire-form.

Graphite, SP-1 grade, for making pellets.

Graphite, 200-mesh, for crucible insulation.

Magnesium Perchlorate, anhydrous, reagent

grade.

Molecular Seive, Linde 5-A.

Nitrogen, liquid.

Polyethylene Beads, 8-mesh.

Schutze Reagent, iodine pentoxide on silica gel, prepare by Smiley's original method. ${ }^{2}$

Uranium Turnings, unoxidized metal.

Vacuum Grease, Fluorlube GR-362.

\section{SAMPLE PREPARATION}

\section{Oxides}

Visually inspect fuel for any signs of contamination, and clean or discard contaminated samples.
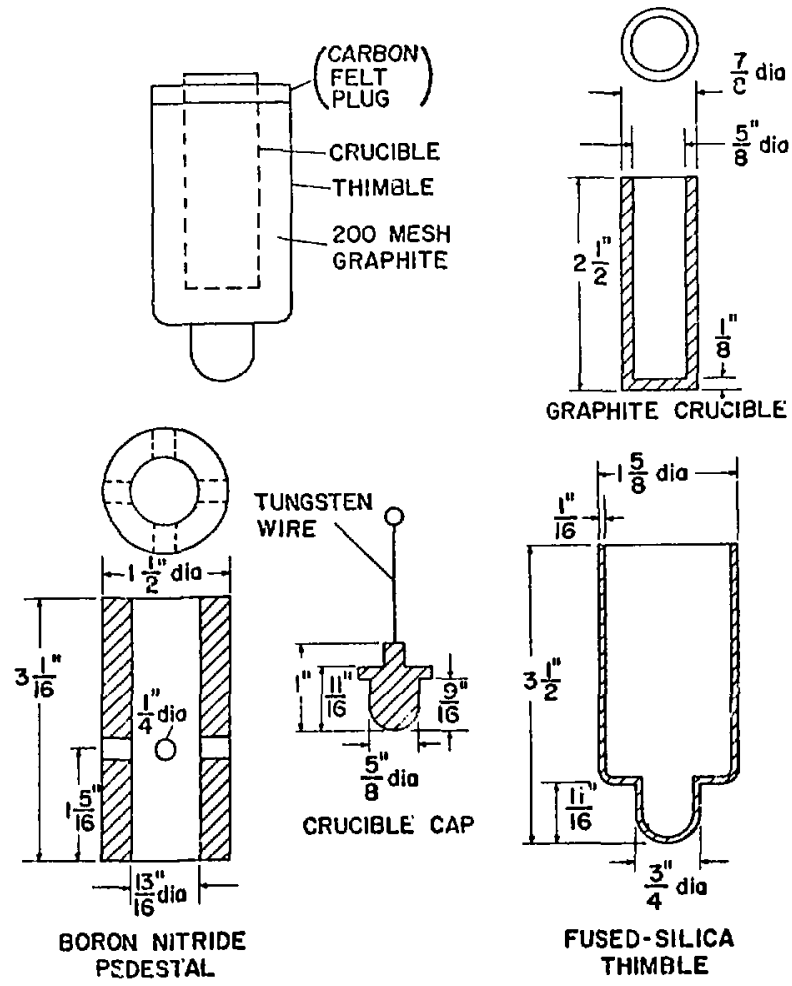

Fig. 6. Pedestal and crucible assemblies.

Place the uncontaminated oxide pellets in the stainless steel mixer-mill capsule, along with a chromesteel ball beíring or, for large numbers of pellets, use the tungsten carbide capsule. Grind and mix the pellets for $2 \mathrm{~min}$ in the mixer-mill, pour the powder into a sample boat, and remove the ball bearing with tweezers. The powder is then ready for pellet preparation.

Cladding

Visually inspect the sample for contamination. In particular, be certain that no fuel adheres to the cladding. Weigh approximately $100 \mathrm{mg}$ within \pm 0.1 $\mathrm{mg}$ and transfer it into a clean sample boat. Handle carbide fuels similarly, but in an inert atmosphere.

\section{RECOMMENDED PROCEDURE}

Caution: Health and safety rules for handling of radioactive materials must be rigidly followed, and adequate protection $r, f$ operators must be ensured by use of a suitable shielded facility and protective clothing. 


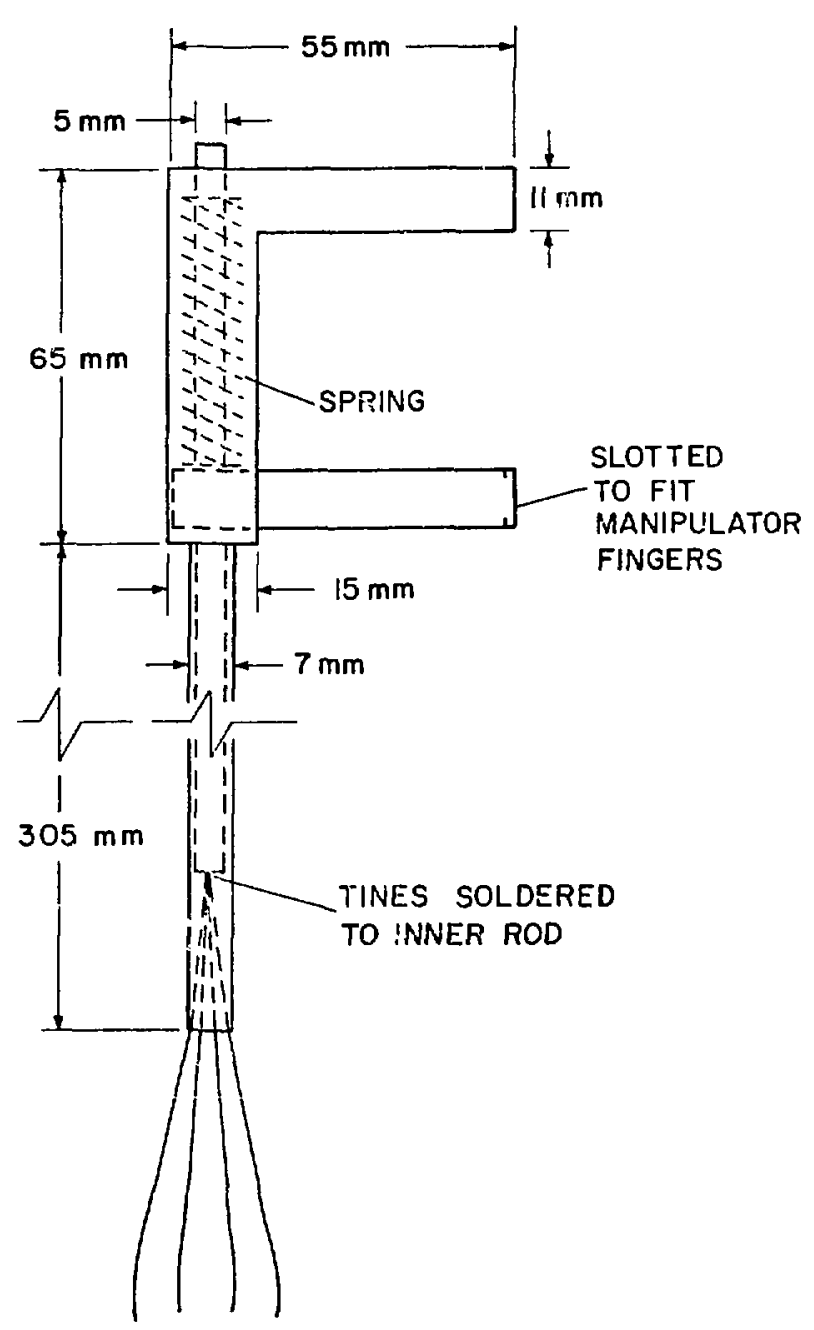

Fig. 7. Pellet-grasping tool.

\section{OXIDE FUEL ANALYSIS}

\section{Pellet Preparation}

1. Accurately weigh ( $(0.1 \mathrm{mg}$ ) approximately $\mathrm{lg}$ of the oxide powder and approximately $0.2 \mathrm{~g}$ of SP-l graphite into a weighed sample boat, and transfer the powders into a blender.

2. Blend the sample for $2 \mathrm{~min}$ and pour the mixed powder through a funnel into the pellet die, using a Vibrograver to vibrate the blending vessel and funnel to ensure nearlv quantitative transfer.

3. Press the mixture into a pellet (8000-1b gauge pressure), replace the bottom half of the die with the pellet trough, and press the pellet into the original sample boat.

4. Weigh the pellet to $\pm 0.1 \mathrm{mg}$ and calculate the
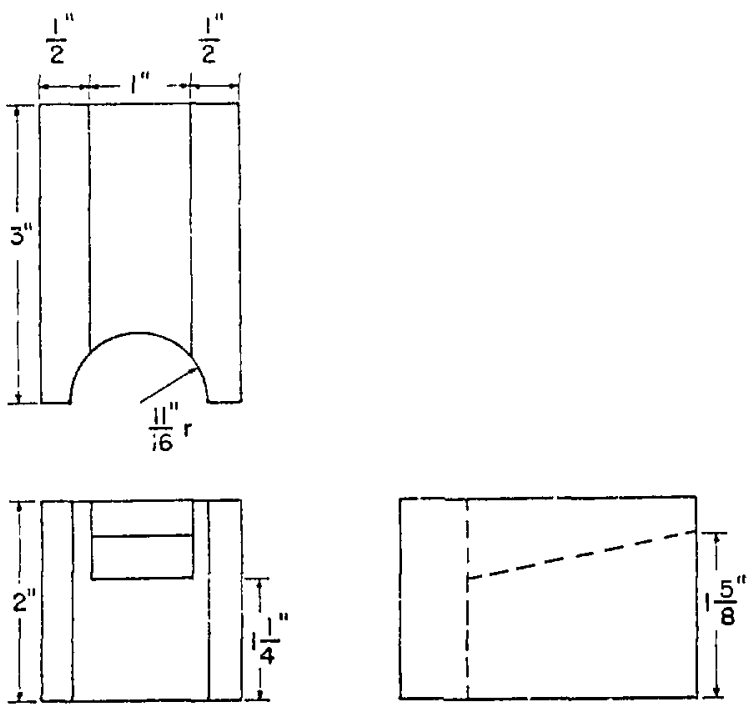

Fig. 8. Pellet trough.

weight of oxide, $W$, in the pellet using

$$
w=\left(\frac{w p}{w_{r}+w_{0}}\right) w_{0},
$$

where

$$
\begin{aligned}
& \mathrm{W}_{0} \quad=\text { original weight of oxide, } \\
& \mathrm{W}_{c} \quad=\text { original weight of carbon, } \\
& \mathrm{W}_{\mathrm{p}} \quad=\text { weight of finished pellet. }
\end{aligned}
$$
(A proportionate loss of both oxide and graphite during pelletizing is assumed. This assumption is less valid the greater the loss, and the precision of the method becomes poorer.)

5. After each pellet is prepared, use the circular brush (Fig. 3) to remove any oxide clinging to the die plunger, and clean the die bore with the 0.27 cal. rifle-brush Moto tool.

6. Clean the stainless steel mixer-mill capsule using the Moto-tool shotgun brush and vibrate the blender capsule with the Vibrograver to make certain that no oxide remains.

Sample Analysis

1. Check the apparatus to be sure that the induction generator is off and that valves $V_{4}, v_{5}$, $V_{6}, S_{5}, S_{6}, S_{7}$, and $S_{8}$ are closed (see Fig. 4 ). Insert weighed absorption tubes into the analysis assembly. 
2. Close $v_{3}$, open $V_{1}$ and $V_{2}$, and adjust the regulator to provide $20-i n$. $\mathrm{H}_{2} \mathrm{O}$ pressure to ensure a positive pressure in the fused-silica furnace tube.

3. Remove the cap from the furnace assembly, remove the crucible cover with long tweezers, and set the cover out of the way.

4. Insert the ample guide tube into the furnace, drop the pellet through the tube into the crucible, remove the guide tube, and replace the crucible cover.

5. Replace the cap on the furnace tube, allowing about $2 \mathrm{~min}$ for the argon from the furnace to purge air from the cap, and then fasten the cap securely in place.

6. Open valves $V_{3}, S_{5}, S_{6}, S_{7}$, and $S_{8}$, and slowly open needle valve $V_{7}$ until the argon flow is $100 \mathrm{ml} / \mathrm{min}$.

7. Turn on the induction generator, and slowly warm the sample from the preset value of $1000{ }^{\circ} \mathrm{C}$ to $2000{ }^{\circ} \mathrm{C}$ in about $25 \mathrm{~min}$.

8. Maintain the $2000{ }^{\circ} \mathrm{C}$ pellet temperature for 1 $h$; then turn off the induction generator, and simultaneously close valves $S_{5}$ and $S_{8}$. followed by valves $S_{6}, S_{7}$, and $V_{3}$.

9. Remove the preweighed Ascarite tubes from the analysis line, wipe them with a damp chamois, allow to sit for $20 \mathrm{~min}$, and then weigh within $\pm 0.1 \mathrm{mg}$.

10. From the weight increases of these two absorption tubes, calculate the amount of oxygen in the sample as follows.

$\operatorname{Oxygen}(\%)=\left[\left(\frac{32.00}{44.01}\right) \mathrm{w}_{1}+\left(\frac{16.00}{44.01}\right)\right] \mathrm{w}_{2} 100 / \mathrm{W}$ where

$$
\begin{aligned}
& W_{1}=\begin{array}{c}
\text { weight increase in Ascarite } \\
\text { tube No. } 1,
\end{array} \\
& W_{2}=\text { weight increase in Ascarite } \\
& W=\text { weight of oxide in pellet. }
\end{aligned}
$$

11. Remove the furnace cap, the crucible cover, and the spent pellet, using 12 -in. tweezers. Replace the crucible cover and furnace cap, and repeat Steps 1 through 10 to analyze another pellet.

\section{CLADDING AND CARBIDE ANA LYSIS}

L. Turn on the argon, adjust the regulator to 5in. gauge pressure, open valves $V_{1}, V_{2}$, and $\mathrm{V}_{4}$, and close valve $\mathrm{V}_{6}$.

2. Turn on the vacuum pump, alowly open valves $V_{6}$ and $V_{5}$, and set the argon flow to $100 \mathrm{ml}$ / min by adjusting valve $V_{B^{*}}$. Measure the gas flow by passing the pump exhaust through a wet-test meter.

3. Close valve $\mathrm{V}_{4}$ and adjust the regulator to 20 in. pressure to create a positive pressure in the furnace tube.

4. Remove the cap from the furnace, insert the sample guide tube into the furnace, and drop the sample into the crucible.

5. Remove the guide tube, replace the cap on the furnace, allow $1 \mathrm{~min}$ for argon from the furnace tube to purge the air from the cap, and then seat the cap firmly with a slight twist.

6. Open valve $\mathrm{V}_{4}$ arid allow argon to flush the line for $1 \mathrm{~min}$.

7. Immerse the capillary trap in a liquid-nitrogen bath, turn on the induction generator, and allow $15 \mathrm{~min}$. for reaction at $2000{ }^{\circ} \mathrm{C}$ and flushing of the reaction producis from the furnace tube.

8. Close valve $V_{5}$, wait about 1 min for the pump to evacuate the capillary manometer, and then close valve $\mathrm{V}_{6}$.

9. Remove the liquid-nitrogen bath from the capillary trap, warm the irap to room temperature, and measure the manometer to $\pm 0.5 \mathrm{~mm}$.

10. Calculate tre micrograms of oxygen using

where

$$
W=0.00086\left(V_{0} x+S x^{2}\right)
$$

$$
\begin{aligned}
\mathrm{W}= & \text { weight of oxygen in micrograms, } \\
\mathrm{V}_{\mathrm{O}}= & \text { volume of } \mathrm{U} \text {-trap in cubic } \\
& \text { millimeters, } \\
\mathrm{S}= & \text { cross section of manometer in } \\
& \text { square millimeters, } \\
\mathrm{x}= & \text { sample pressure in millimeters. }
\end{aligned}
$$

11. Determine an apparatus blank by performing Steps 1 through 10, but omit addition of the sample in Step 4.

12. Subtract the micrograms of oxygen in the blank from the total micrograms found in the sample. 


\section{EXPERIMENTAL.}

A discussion of the chemical aspects of the method, including gas purification, sample preparation, and the manometric and gravimetric measurements is given in previous reports. ${ }^{1-3}$ The major problem in modifying the methods for hotcell use was the design of new hardware to facilitate remote maintenance and operation of the equipment. Because of the long leads from the power generatur to the induction coil, an insulated crucible was used to maximize the usable power. To avoid use of powdered giaphite insulation that might react slightly with the fused-silica thimble, we tried pyrolytic boron nitride (200-mesh) insulation. At $2000^{\circ} \mathrm{C}$, however, we obtained a high apparatus blank ( $80 \mu \mathrm{g} \mathrm{O}_{2}$ ). We tried to bake the thimble assembly at $2200^{\circ} \mathrm{C}$ and then lower the temperature to $2000{ }^{\circ} \mathrm{C}$ for analyzing samples. The boron nitride began to decompose at above $2000{ }^{\circ} \mathrm{C}$, and the decomposition products attacked the carbon crucible. Therefore, we did not persue use of boron nitride further, and selected powdered graphite insulation. With the graphite insulation, a preliminary baking of the assembly at $2500{ }^{\circ} \mathrm{C}$ before operation at $2000{ }^{\circ} \mathrm{C}$ reduced the apparatus blank to $5 \mu \mathrm{g}$ of oxygen.

The thimble assembly facilitated handling and replacement of the crucibles in the hot cell. Thimble and crucible assemblies were fabricated in advance cutside the cell, and whole units were replaced as needed without difficulties.

A new type of fused-silica furance was designed for use in the hot cell. The modifications consisted primarily of a wide top opening that permitted removal of oxide pellets from the dry crucible, and a wide flanged bottom opening for easy replacement of the thimble assembly. A brass base plate mechanically raised the pedestal and crucible assembly into place, and at the same time, made a seal between the base and the furnace tube. Water lines were connected to the water jacket through ball joints, as opposed to nipples, to facilitate making the connection with manipulators.

The silicone high-vacuum grease, previously used to make leaktight seals outside the hot cell, deteriorated upon exposure to high-level radiation. Fluorlube GR-362, which remained pliable under irradiation and also maintained vacuum seals at the operating temperature of the apparatus, was found to be satisfactory.

We designed numerous small tools for adapting the pellet-making process to the hot cell. These included funnels for powder transfer, tweezers for reaching into the furnace and removing the pellet, brushes for cleaning the equiprnent, and guides for positioning equipment to circumvent the loss of depth-perception inherent in remote operation. These are described more fully in the section on Apparatus.

\section{RELIA BILITY}

The method and apparatus were evaluated for determining oxygen in oxides using a test sample of uranium oxide $\left(\mathrm{U}_{3} \mathrm{O}_{8}\right)$ prepared from uranium metal containing less than $100 \mathrm{ppm}$ of total detected impurities. The calculated oxygen content based on the weight increase was $15.24 \%$. An average value of $15.25 \%$ oxygen was measured in the hot cell. The precision of the method was 0.1 to $0.2 \%$ which was comparable to that obtained using the method outside the hot cell. Irradiated samples were then analyzed with the results shown in Table I.

\section{Table I}

ANALYSES OF IRRADIATED OXIDE FUELS FOR OXYGEN

\begin{tabular}{|c|c|c|c|c|}
\hline Sample & $\begin{array}{c}\text { Burnup } \\
(\%)\end{array}$ & $\begin{array}{c}\text { Oxygen } \\
(\%)\end{array}$ & $\begin{array}{l}\text { No. } \\
\text { Analyses }\end{array}$ & $\begin{array}{l}\text { Relative } \\
\text { Standard } \\
\text { Deviation ( } \% \text { ) }\end{array}$ \\
\hline 1 & 6.29 & 11.97 & 3 & -- \\
\hline 2 & 6.06 & 11.74 & 8 & 0.4 \\
\hline 3 & unknown & 11.95 & 6 & 0.3 \\
\hline 4 & 8.50 & 11.94 & 5 & 0.2 \\
\hline 5 & unknown & 11. 86 & 5 & 0.9 \\
\hline
\end{tabular}

Unfortunately, an irradiated oxide fuel standard of known $\mathrm{O}_{2}$ content was not available, but analysis of the $\mathrm{U}_{3} \mathrm{O}_{8}$ sample indicated adequate accuracy for the equipment. We found no difficulties that could be attributed to the high radiation level.

We have made analyses for micro quantities of oxygen on three unirradiated samples, and have compared the results with those obtained on an inert-gas-fusion apparatus in a "cold" area (see Table II). 
Table II

OXYGEN ANA LYSIS RESULTS OBTAINED INSIDE AND OUTSIDE THE HOT CELL

$\frac{\text { Sample }}{\mathrm{Nb}}$

$\mathrm{NbC}$

W-Mo

\begin{tabular}{cc}
\multicolumn{2}{c}{ Oxygen Content (ppm) } \\
$\frac{\text { In ColI }}{2300}$ & $\frac{\text { Out of CeII }}{2300}$ \\
925 & 1000 \\
2500 & 2200
\end{tabular}

As these data show, the results obtained in the hot cell and outside it are essentially equal.

Samples of irradiated stainless steel cladding have been aralyzed, but again, no irradiated standards were available, and comparison with another apparatus was impossible owing to lack of another facility for analyzing the highly radioactive cladding for oxygen. However, unirradiated steel samples are analyzed routinely by this method outside the cell.

\section{SUMMARY}

Two methods for measuring oxygen have been successfully adapted for use in a hot cell to measure the oxygen in irradiated fuels and claddings. The apparatus is very versatile, being able to measure 5 - $\mathrm{gg}$ to 130-mg quantities of oxygen. Approximately 2 analyses of oxides or 10 analyses of cladding materials can be performed in $B \mathrm{~h}$.

\section{ACKNOW LEDGMENTS}

We greatfully acknowledge the assistance of the members of the Hot Cell Group, CMB-14, under John W. Schulte, for the design and instalation of the mechanized equipment for the remote facility.

\section{REFERENCES}

1. C. S. MacDougall, M. E. Smith, and G. R. Waterbury, Anal. Chem. 4l, 372 (1969).

2. W. G. Smiley, Anal. Chem. 27, 1098 (1955).

3. W. G. Smiley, Los Alamos Scientific Laboratory report LA -1733 (1954).

4. C. S. MacDougall, M. S. Smith, and G. R. Waterbury "Remotized Apparatus for Determining Oxygen in Irradiated Reactor Fuels and Cladding Materials, "Proc. 20th Conf. Remote Systems Technology, Idaho Falls, Idaho, 1972.

5. J. R. Lilienthal, "Los Alamos Alpha Gamma Cells, "Proc. 7th Conf. Hot Laboratories and Equipment, Idaho Falls, Idaho, April 7-9, 1959, pp. 292-304.

6. C. C. Burwell, J. W. Schulte, and M. T. Wilson, "The Los Alamos 'Wing 9' Alpha-Gamma Box, " Proc. 12th Conf. Remote Systems Technology, Idaho Falls, Idaho, 1964. 